\title{
The Effects of Nutrients on Fungi and Aflatoxin Contamination in Peanut
}

\author{
Isilay Lavkor \\ Biological Research Institue \\ Kisla St. 01321 Yuregir, Adana, Turkey \\ E-mail: isilay.lavkor@tarimorman.gov.tr
}

\begin{abstract}
The effects of nutrients on fungi and aflatoxin contamination were determined in peanut in this study. For this aim, total of 40 peanuts samples from harvest and storage periods were collected from Osmaniye province of Turkey. Aspergillus niger (13,00-28,00\%), A. flavus (1,00-8,00\%) Fusarium solani (1,00$18,00 \%), F$. oxysporum $(1,00-17,00 \%), F$. sambicinum $(1,00-9,00 \%)$, F. semitectum $(1,00-7,00 \%)$, Rhizoctonia solani (3,00-18,00\%), Macrophomina phaseolina (2,00-24,00\%) and Rhizopus stolonifer $(16,00-35,00 \%)$ were isolated on peanuts taking from harvest and storage. A. parasiticus $(1,00 \%)$ and Penicillium spp. (6,00-15,00\%) were isolated only from the storage. The consequences of mineral analysis were showed that all minerals diminished with storage. In harvest and storage, $\mathrm{K}$ and $\mathrm{N}$ levels were insufficient while $\mathrm{P}, \mathrm{Fe}, \mathrm{Cu}, \mathrm{Zn}$ and $\mathrm{Mn}$ levels were within an agreeable ranges, as well as in storage, generally $\mathrm{Ca}$ levels was under the critical level. Total aflatoxin contamination in peanut was performed by HPLC (High-Performance Liquid Chromatography). Toxin levels were between 0.21 and $22.17 \mathrm{ppb}$ in 40 peanut samples. Aflatoxin content during storage was significantly higher than harvest. The results of this study, the reduce of mineral nutrients were attributed to fungi and aflatoxin contamination in peanut.
\end{abstract}

Key words: Fungi, Aflatoxin, Nutrient, Peanut, Harvest, Storage

DOI: $10.7176 / J S T R / 5-2-20$

\section{Introduction}

One of the imost important legume crop is groundnut or peanut (Arachis hypogea L.). Also, peanut is a main annual oilseed, protein sources (Asibuo et al., 2008) and vitamins (vitamin $\mathrm{B}_{1}, \mathrm{~B}_{2}, \mathrm{~B}_{6}$, nicotinic acid) (Pursglove, 1984; Arioglu, 2000). It contains many of minerals as potassium, phosphorus, magnesium and calcium (Savage and Keenan, 1994). In the world, peanut is grown in China (42\%), Indian (15\%), Nigeria $(7 \%)$ and USA $(5 \%)$, respectively. Turkey has produced about $0.26 \%$ of peanut production in the world (Kadiroglu, 2012).

Peanut seeds are engaged as Rhizopus spp., Penicillium spp., Aspergillus niger and A. flavus serve a source of stored nutrients for fungi (Sullivan, 1984). Fungi contribute to pre and post harvest deterioration of peanuts (Leslei and Summerell, 2006), and inducing physical and biochemical damage to the crops when stored under conditions appropriate for their growth (Ingale and Shrivastava, 2011). Several authors isolated fungi from peanut seeds as Fusarium spp., Aspergillus spp., Penicillium spp., Pythium spp., Macrophomina phaseolina, Alternaria spp., Trichothecium, Rhizopus spp., Botrytis cinerea, Helminthosporium spp., Mucor spp., Curvularia sp., Chaetomium sp. (Abou-Talip, 1970; El-Khadem et al., 1975; El-Akkad 1982; Porter et al., 1990; Richardson 1990; Baird et al., 1993; Drahmaputra and Retnowati, 1996). Aflatoxins causing major economic losses are produced by A. flavus and A. parasiticus (Varga et al., 2009).

In addition, mechanical forces are subsidiary to gaining reach to nutrients whereby fungal hyphal tips grow into and through peanuts (Nielsen et al., 2009). Starches, hemicelluloses, celluloses, pectins and other sugar polymers are played important role to produce by fungi. The most separation consist when the nitrogen, phosphorus and other necessary inorganic nutrients are sufficient (Agrois, 1997).

Moreover, of the essential nutrient elements play an important role in infection of plant product. Nitrogen deficiency and other stresses predispose corn to infection by Aspergillus spp. and aflatoxin concentration in grain were $28 \%$ higher in N-deficient plants than in N-sufficient plant (Payne et al., 1989). Potassium and $\mathrm{Mg}$ were decreased $\mathrm{Ca}$ in peanut pods and predispose them to infection by $R$. solani and Pythium 
(Huber, 1980). Calcium availability in peanuts can be effected both A. flavus and aflatoxin contamination on peanut kernels (Rahman and Punja, 2007). Aspergillus species are strongly affected by zinc. Failla et al. (1986), found a significant $(\mathrm{P}<0.05)$ correlation between $\mathrm{Zn}^{2+}$ contents and aflatoxin content of 49 samples of corn. Also, zinc deficiency was reduced the growth, sporulation and attenuates the virulance of $F$. oxysporum (Dufy, 2007).

In Turkey, there is no any research related to the plant nutritions, diseases and aflatoxin. For this aim, this study was carried out to determine the effects of contamination of fungi and mineral nutritions on peanut seeds with aflatoxin during harvest and storage.

\section{Materials and Methods}

\subsection{Collection of peanut samples}

Number of twenty peanut in shell samples were collected at harvest from Osmaniye in Turkey. Each samples were obtained from different farmer fields. Collected samples (about $2 \mathrm{~kg}$ each) were divided about $250 \mathrm{~g}$ for analyzing nutrient element content and kernels infected by fungi. Twenty storage peanut samples (about $1 \mathrm{~kg}$ each) were also obtained for analyzing nutrient element, aflatoxin analysis and isolation of fungi (Lavkor, 2013). Samples were kept at $4^{\circ} \mathrm{C}$.

\subsection{Fungi isolation and identification}

Fungal isolation was done on lot 100 seeds of each peanut sample were surface sterilized in $2 \%$ sodium hypochlorite solution for one minute then rinsed twice with sterile distilled water.

and dried on sterilized filter paper. From each sample 100 seeds were placed in the PDA (potato dextrose agar) medium. Petri dishes were placed in a incubator at temperature of $25 \pm 2{ }^{\circ} \mathrm{C}$ for seven days. At the end of this period the resulting fungal colonies were individually sub - cultured onto fresh potato dextrose agar to obtain pure cultures. Observations on colony colour were made. Each fungal colony was examined under light microscope. Vegetative and fruiting bodies of the isolates of fungal species were identified using mycological keys and manuals (Lavkor, 2013). The isolates of fungal species were identified using mycological keys and manuals (Ellis, 1971, Barnett and Hunter, 1972; Domsch et al., 1980; Booth, 1971; Nelson et al., 1983; Raper and Fennel, 1977; Pitt, 2000; Klich, 2002; Summerell et al., 2003).

\subsection{Nutrient Element Analysis}

Peanut seed samples $(0.4 \mathrm{~g})$ were splited in $5 \mathrm{~mL} \mathrm{HNO}_{3}$ and $2 \mathrm{~mL} \mathrm{H}_{2} \mathrm{O}$ in closed microwave digestion system (MARSxpress, CEM Corp.). After Samples were analyzed for K, Ca, Mg, S, Zn, Fe, Cu, Mn using inductively coupled plasma optical emission spectrometer (ICP-OES; Vista-Pro Axial; Varian Pty Ltd, Mulgrave, Australia). Determination of nitrogen was based on AOAC method 997.09 (AOAC, 1984) with a 0.2 g sample.

\subsection{Detection of Aflatoxin Using High Performance Liquid Chromatography (HPLC)}

The samples were analysed according to AOAC method (AOAC, 2005). Fifty grams of each sample was milled and sieved using a 20 mesh sieve to obtain fine flour. Ten grams of each sample was obtained and placed in a conical flask containing five gram of sodium chloride and $150 \mathrm{ml}$ of extraction solution (methanol/water $(80 / 20, \mathrm{v} / \mathrm{v})$ ). The mixture was shaken at $250 \mathrm{rpm}$ for $2 \mathrm{~min}$ using an orbital shaker (model Heidophunimax 2010) followed by centrifugation (Model 6000 Centurion) at $4000 \mathrm{rpm}$ at $5{ }^{\circ} \mathrm{C}$ for 5 minutes. The extract was filtered through a Whatman No.1 filter. After filtration, $15 \mathrm{ml}$ of the filtrate was diluted with $40 \mathrm{ml}$ of distilled water. Thereafter, $10 \mathrm{ml}$ was passed through aflatest immune affinity column (VICAM, 100 Watertown) fitted on a solid phase manifold at a flow rate of $1 \mathrm{drop} / \mathrm{sec}$. The immunoaffinity column was washed with $15 \mathrm{ml}$ water. Aflatoxins were eluted with three millilitre methanol into a $4 \mathrm{ml}$ amber vial and then stored at $4{ }^{\circ} \mathrm{C}$ until analysis.

Aflatoxins were analyzed using Agilent 1100 HPLC. The fluorescence detector was set at excitation of $365 \mathrm{~nm}$ and emission of $440 \mathrm{~nm}$. The mobile phase of water/methanol/acetonitrile (560/260/180) at flow rate of $1.0 \mathrm{ml} / \mathrm{min}$. The data was stated as a ppb.

\section{Results}

Fungi isolation was performed in both at harvest and storage on total 40 different peanut seed samples. Aspergillus niger (13,00-19,00\%), A. flavus (0,00-5,00 \%) Fusarium solani (5,00-18,00 \%), F. oxysporum (1,00-7,00 \%), F. sambicinum (3,00-9,00 \%), F. semitectum (1,00-6,00 \%), R. solani (9,00-18,00\%), M. phaseolina (12,00-24,00 \%) and R. stolonifer (21,00-35,00\%) were determined on seed samples of the harvest (Table 1). A. niger (23,00-19,00\%), A. flavus (0,2-8,00\%), A. parasiticus (0,00-1,00\%) Fusarium solani (0,00-7,00\%), F.oxysporum (10,00-19,00\%), F sambicinum (0,00-5,00\%), F. semitectum (2,00- 
7,00 \%), Penicillium sp. (6,00-15,00\%), R. solani (3,00-10,00\%), M. phaseolina (2,00-8,00\%) and $R$. stolonifer $(16,00-28,00 \%)$ were determined on seed samples of the storage (Table 1).

The results of mineral nutrients $(\mathrm{N}, \mathrm{P}, \mathrm{K}, \mathrm{Ca}, \mathrm{Mg}, \mathrm{S}, \mathrm{Zn}, \mathrm{Fe}, \mathrm{Cu}, \mathrm{Mn}$ ) were determined by according to Freeman et al. (1954) (Table 2). Outcome of the mineral analysis (mg/100 g) showed that all minerals diminished during storage. At harvest, potassium $(\mathrm{K})(600,00-651,86)$ and nitrogen $(\mathrm{N})(3,44-3,97)$ levels were insufficient while phosphorus (P) (248,76-298,73), calcium (Ca) (20,12-25,65), magnesium $(\mathrm{Mg})$ $(109,17-222,82)$, sulfur (S) $(198,65-219,79)$, zinc $(\mathrm{Zn})(2,00-7,83)$, iron $(\mathrm{Fe})(2,63-13,87)$, copper $(\mathrm{Cu})$ $(1,63-6,15)$ and manganese $(\mathrm{Mn})(1,12-6,35)$ levels were within the accepted ranges. In the storage, potassium $(\mathrm{K})(600,10-670,02)$ and nitrogen $(\mathrm{N})(3,25-3,67)$ levels were insufficient while phosphorus $(\mathrm{P})$ (253,67-287,82,73), magnesium (Mg) $(92,64-108,24)$, sulfur (S) $(202,10-227,05)$, zinc $(\mathrm{Zn})(8,04-16,05)$, iron $(\mathrm{Fe})(2,48-10,41)$, copper $(\mathrm{Cu})(6,11-12,75)$ and manganese $(\mathrm{Mn})(6,96-13,57)$ levels were within the accepted ranges as well as in storage, generally calcium (Ca) $(12,83-19,67)$ level was under the critical level.

As can be seen in Table 3, the total aflatoxins content were performed both at harvest and storage on total 40 different peanut seed samples. Aflatoxin $\mathrm{B}_{1}$ in harvest peanut samples were found in range of 0,15 to $1,54 \mathrm{ppb}$. Aflatoxin $\mathrm{B}_{2}$ was ranged from 0,08 to $0,95 \mathrm{ppb}$. Total aflatoxins content were $0,00-2,49 \mathrm{ppb}$. In storege period, aflatoxin $\mathrm{B}_{1}$ was determined 2,15 to $8,36 \mathrm{ppb}$. Aflatoxin $\mathrm{B}_{2}$ was ranged from 0,93 to 2,85 $\mathrm{ppb}$, aflatoxin $\mathrm{G}_{1}$ content was 2,53-9,10 ppb. While aflatoxin $\mathrm{G}_{2}$ was found $0,64-2,82 \mathrm{ppb}$ on seed samples of the storage. Total aflatoxins were determined in range of 3,96 to $22,17 \mathrm{ppb}$. 
Table 1. Isolation of peanut seeds at harvest and from storage and isolating rates (\%)

\begin{tabular}{|c|c|c|c|c|c|c|c|c|c|c|c|c|c|c|c|c|c|c|c|c|c|}
\hline \multirow[b]{3}{*}{ Name of Fungi } & \multicolumn{21}{|c|}{ No of samples } \\
\hline & \multicolumn{20}{|c|}{ Fungi isolation of peanut seeds from harvest and isolating rates (\%) } & \multirow[b]{2}{*}{$\begin{array}{l}\text { Mean } \\
\text { Total }\end{array}$} \\
\hline & 1 & 2 & 3 & 4 & 5 & 6 & 7 & 8 & 9 & 10 & 11 & 12 & 13 & 14 & 15 & 16 & 17 & 18 & 19 & 20 & \\
\hline A. niger & 17,00 & 19,00 & 18,00 & 16,00 & 19,00 & 14,00 & 16,00 & 13,00 & 18,00 & 15,00 & 19,00 & 15,00 & 16,00 & 16,00 & 17,00 & 19,00 & 17,00 & 15,00 & 17,00 & 15,00 & 16,55 \\
\hline A. flavus & 2,00 & 1,00 & 0,00 & 2,00 & 1,00 & 1,00 & 1,00 & 0,00 & 0,00 & 2,00 & 2,00 & 1,00 & 5,00 & 2,00 & 1,00 & 2,00 & 1,00 & 1,00 & 4,00 & 2,00 & 1,55 \\
\hline F. solani & 11,00 & 12,00 & 9,00 & 14,00 & 6,00 & 17,00 & 4,00 & 10,00 & 16,00 & 18,00 & 11,00 & 16,00 & 12,00 & 9,00 & 14,00 & 8,00 & 9,00 & 5,00 & 6,00 & 7,00 & 10,70 \\
\hline F. oxysporum & 5,00 & 7,00 & 6,00 & 3,00 & 7,00 & 4,00 & 4,00 & 1,00 & 9,00 & 5,00 & 2,00 & 3,00 & 6,00 & 4,00 & 1,00 & 4,00 & 2,00 & 1,00 & 5,00 & 3,00 & 4,10 \\
\hline F sambicinum & 5,00 & 8,00 & 5,00 & 6,00 & 7,00 & 5,00 & 6,00 & 3,00 & 5,00 & 4,00 & 4,00 & 7,00 & 6,00 & 5,00 & 8,00 & 7,00 & 5,00 & 6,00 & 9,00 & 6,00 & 5,85 \\
\hline F. semitectum & 2,00 & 1,00 & 5,00 & 1,00 & 1,00 & 6,00 & 3,00 & 4,00 & 2,00 & 1,00 & 4,00 & 2,00 & 1,00 & 2,00 & 2,00 & 2,00 & 3,00 & 5,00 & 2,00 & 4,00 & 2,65 \\
\hline$R$. solani & 11,00 & 12,00 & 14,00 & 9,00 & 14,00 & 12,00 & 13,00 & 10,00 & 9,00 & 15,00 & 12,00 & 10,00 & 15,00 & 13,00 & 11,00 & 17,00 & 18,00 & 12,00 & 17,00 & 15,00 & 12,95 \\
\hline M. phasolina & 19,00 & 15,00 & 16,00 & 18,00 & 21,00 & 16,00 & 22,00 & 24,00 & 16,00 & 19,00 & 22,00 & 17,00 & 17,00 & 16,00 & 18,00 & 22,00 & 17,00 & 20,00 & 12,00 & 23,00 & 18,50 \\
\hline \multirow[t]{2}{*}{ R. stolonifer } & 28,00 & 25,00 & 23,00 & 32,00 & 23,00 & 25,00 & 31,00 & 35,00 & 25,00 & 21,00 & 24,00 & 29,00 & 22,00 & 33,00 & 28,00 & 19,00 & 28,00 & 35,00 & 28,00 & 25,00 & 26,95 \\
\hline & \multicolumn{21}{|c|}{ Fungi isolation of peanut seeds from storage and isolating rates $(\%)$} \\
\hline A. niger & 23,00 & 27,00 & 26,00 & 28,00 & 24,00 & 27,00 & 23,00 & 28,00 & 25,00 & 23,00 & 24,00 & 27,00 & 23,00 & 25,00 & 27,00 & 23,00 & 28,00 & 27,00 & 23,00 & 28,00 & 25,45 \\
\hline A. flavus & 5,00 & 7,00 & 2,00 & 6,00 & 4,00 & 7,00 & 3,00 & 2,00 & 5,00 & 6,00 & 4,00 & 3,00 & 8,00 & 5,00 & 4,00 & 6,00 & 8,00 & 6,00 & 8,00 & 5,00 & 5,20 \\
\hline A. parasiticus & 0,00 & 1,00 & 0,00 & 1,00 & 0,00 & 0,00 & 0,00 & 0,00 & 0,00 & 0,00 & 0,00 & 0,00 & 1,00 & 0,00 & 0,00 & 0,00 & 0,00 & 0,00 & 1,00 & 0,00 & 0,20 \\
\hline F. solani & 6,00 & 3,00 & 2,00 & 4,00 & 0,00 & 1,00 & 3,00 & 4,00 & 1,00 & 7,00 & 5,00 & 6,00 & 4,00 & 2,00 & 4,00 & 5,00 & 0,00 & 5,00 & 4,00 & 1,00 & 3,35 \\
\hline F. oxysporum & 13,00 & 16,00 & 15,00 & 17,00 & 14,00 & 10,00 & 15,00 & 16,00 & 14,00 & 13,00 & 19,00 & 15,00 & 14,00 & 14,00 & 16,00 & 16,00 & 13,00 & 10,00 & 15,00 & 13,00 & 14,40 \\
\hline F sambicinum & 2,00 & 1,00 & 4,00 & 1,00 & 3,00 & 2,00 & 0,00 & 2,00 & 4,00 & 1,00 & 3,00 & 2,00 & 3,00 & 0,00 & 2,00 & 1,00 & 3,00 & 2,00 & 4,00 & 5,00 & 2,25 \\
\hline F. semitectum & 5,00 & 5,00 & 4,00 & 7,00 & 3,00 & 4,00 & 6,00 & 4,00 & 4,00 & 5,00 & 3,00 & 4,00 & 5,00 & 3,00 & 3,00 & 4,00 & 3,00 & 2,00 & 4,00 & 5,00 & 4,15 \\
\hline Penicillium spp. & 13,00 & 9,00 & 11,00 & 9,00 & 8,00 & 10,00 & 15,00 & 8,00 & 11,00 & 7,00 & 6,00 & 14,00 & 9,00 & 9,00 & 6,00 & 12,00 & 7,00 & 9,00 & 6,00 & 9,00 & 9,40 \\
\hline R. solani & 7,00 & 4,00 & 8,00 & 5,00 & 9,00 & 3,00 & 6,00 & 7,00 & 7,00 & 10,00 & 8,00 & 5,00 & 5,00 & 6,00 & 7,00 & 5,00 & 8,00 & 7,00 & 6,00 & 7,00 & 6,50 \\
\hline M. phaseolina & 6,00 & 7,00 & 6,00 & 5,00 & 7,00 & 8,00 & 4,00 & 5,00 & 2,00 & 5,00 & 8,00 & 8,00 & 4,00 & 7,00 & 3,00 & 4,00 & 6,00 & 8,00 & 2,00 & 7,00 & 5,60 \\
\hline$R$. stolonifer & 20,00 & 20,00 & 22,00 & 17,00 & 28,00 & 28,00 & 25,00 & 24,00 & 27,00 & 23,00 & 20,00 & 16,00 & 24,00 & 29,00 & 28,00 & 24,00 & 24,00 & 24,00 & 27,00 & 20,00 & 23,50 \\
\hline
\end{tabular}


International Journal of Scientific and Technological Research

www.iiste.org ISSN 2422-8702 (Online), DOI: 10.7176/JSTR/5-2-20

Vol 5, No.2, 2019

Table 2. Nutrient element contents of peanut in the survey areas in both at harvesting and storage

\begin{tabular}{|c|c|c|c|c|c|c|c|c|c|c|}
\hline \multirow{3}{*}{\begin{tabular}{|l|}
$\begin{array}{l}\text { No of } \\
\text { samples }\end{array}$ \\
\end{tabular}} & \multicolumn{10}{|c|}{ Nutrient element contents of peanuts in the survey areas from harvest } \\
\hline & $\mathbf{N}$ & $\mathbf{P}$ & $\mathbf{K}$ & $\mathbf{C a}$ & Mg & $\mathbf{S}$ & Zn & Fe & $\mathbf{C u}$ & Mn \\
\hline & \multicolumn{10}{|c|}{$\mathrm{mg} / 100 \mathrm{~g}$} \\
\hline 1 & 3,76 & 269,49 & 612,38 & 20,14 & 201,14 & 209,62 & 2,35 & 8,75 & 3,58 & 3,21 \\
\hline 2 & 3,56 & 253,77 & 621,25 & 22,63 & 206,56 & 212,74 & 6,58 & 4,78 & 4,85 & 1,52 \\
\hline 3 & 3,93 & 249,53 & 647,26 & 21,90 & 224,25 & 212,95 & 5,21 & 13,87 & 2,12 & 5,16 \\
\hline 4 & 3,78 & 251,17 & 614,98 & 22,67 & 211,12 & 205,31 & 4,27 & 7,15 & 5,11 & 2,34 \\
\hline 5 & 3,67 & 249,15 & 601,59 & 21,27 & 207,13 & 213,95 & 7,83 & 6,17 & 4,76 & 4,12 \\
\hline 6 & 3,83 & 253,55 & 643,53 & 20,65 & 210,34 & 215,13 & 7,12 & 11,75 & 2,15 & 2,11 \\
\hline 7 & 3,69 & 252,83 & 612,53 & 23,39 & 221,64 & 206,33 & 4,66 & 9,36 & 6,15 & 6,35 \\
\hline 8 & 3,78 & 248,76 & 600,10 & 24,11 & 203,21 & 215,73 & 1,98 & 6,43 & 1,83 & 1,12 \\
\hline 9 & 3,54 & 251,52 & 652,12 & 21,53 & 205,24 & 205,33 & 2,00 & 10,65 & 2,35 & 1,22 \\
\hline 10 & 3,72 & 259,17 & 642,45 & 23,58 & 214,85 & 223,36 & 3,76 & 3,08 & 6,94 & 5,11 \\
\hline 11 & 3,97 & 251,74 & 613,33 & 21,53 & & 203,84 & 6,02 & 14,32 & 5,15 & 2,20 \\
\hline 12 & 3,57 & 252,93 & 602,30 & 22,60 & 22 & 198,65 & 5,62 & 9,98 & 6,27 & 6,14 \\
\hline 13 & 3,44 & 270,94 & 634,37 & 23,26 & 214,21 & 207,37 & 6,58 & 2,63 & 2,17 & 2,15 \\
\hline 14 & 3,50 & 261,14 & 615,26 & 22,91 & & 216,78 & 4,67 & 2,96 & 3,20 & 3,35 \\
\hline 15 & 3,92 & 272,13 & & 25 & & 223,64 & 3,65 & 33 & 1,63 & 4,78 \\
\hline 16 & 3,51 & 283,97 & & 20,12 & & 205,18 & 3,24 & 3,90 & 1,33 & 3,07 \\
\hline 17 & 3,72 & 298,73 & 620,67 & 24,11 & 218 & 208,76 & 4,63 & 5,74 & 2,50 & 2,95 \\
\hline 18 & 3,68 & 258,34 & 602,78 & 21,64 & 221 & 211,17 & 2,63 & 10,38 & 5,44 & 4,48 \\
\hline 19 & 3,75 & 273,25 & 617 & 23 & & 210,13 & 5,65 & 6,40 & 3,53 & 3,82 \\
\hline 20 & 3,58 & & & & & & & & 2,49 & 2,44 \\
\hline \multirow[t]{2}{*}{$\begin{array}{l}\text { Mean } \\
\text { Total }\end{array}$} & 3,70 & 262,69 & 600,64 & 22,49 & 208,17 & 211,29 & 4,60 & 7,79 & 3,68 & 3,38 \\
\hline & \multicolumn{10}{|c|}{ Nutrient element contents of peanuts in the survey areas from storage } \\
\hline \multirow{2}{*}{$\begin{array}{l}\text { No of } \\
\text { samples }\end{array}$} & $\mathbf{N}$ & $\mathbf{P}$ & $\mathbf{K}$ & $\mathbf{C a}$ & Mg & $\mathbf{S}$ & $\mathbf{Z n}$ & Fe & $\mathbf{C u}$ & Mn \\
\hline & \multicolumn{10}{|c|}{$\mathrm{mg} / \mathbf{1 0 0} \mathrm{g}$} \\
\hline 1 & 3,67 & 258,49 & 616,50 & 18,53 & 102,81 & 211,28 & 13,56 & 5,28 & 5,44 & 12,25 \\
\hline 2 & 3,48 & 261,04 & 618,18 & 16,88 & 24 & 213,13 & 8,75 & 2,74 & 6,37 & 11,90 \\
\hline 3 & 3,57 & 259,53 & 630,54 & 14,38 & 93,02 & 226,18 & 8,94 & 8,24 & 7,51 & 9,65 \\
\hline 4 & 3,40 & 255,27 & 617,82 & 19,59 & & 210,14 & 9,33 & 4,38 & 6,66 & 6,15 \\
\hline 5 & 3,61 & 287,82 & 605,02 & 18 & & 214,57 & 16,05 & 8,88 & 8,05 & 12,57 \\
\hline 6 & 3,72 & 253,35 & 620,81 & 14,41 & 20 & 228,39 & 10,01 & 9,11 & 6,11 & 6,51 \\
\hline 7 & 3,65 & 278,59 & 646,37 & 13,30 & & 203,04 & 14,54 & 6,84 & 5,49 & 7,10 \\
\hline 8 & 3,56 & 281,76 & 618,48 & 17,67 & 54 & 206,21 & 12,24 & 10,41 & 9,26 & 11,13 \\
\hline 9 & 3,43 & 265,49 & 602,17 & 12,83 & 83 & 206,70 & 8,51 & 4,10 & 7,35 & 9,43 \\
\hline 10 & 3,36 & 257 & & & & & 8,43 & 7,99 & 12,54 & 8,25 \\
\hline 11 & 3,43 & 272,43 & 51 & 19,46 & 95 & 223,43 & 11,94 & 3,53 & 4,75 & 11,35 \\
\hline 12 & 3,25 & 255,17 & 614,16 & 19,32 & 94,41 & 217,84 & 9,82 & 7,59 & 9,17 & 12,50 \\
\hline 13 & 3,31 & 267,16 & 615,12 & 16,94 & 105,25 & 221,65 & 12,84 & 8,65 & 9,27 & 11,70 \\
\hline 14 & 3,28 & 273,53 & & & & & 8,04 & 2,92 & 8,15 & 12,36 \\
\hline 15 & 3,35 & & 670 & & 23 & & 9,72 & 5,30 & 7,64 & 6,96 \\
\hline 16 & 3,78 & 253,67 & 616,97 & 19,67 & 97,73 & 218,85 & 13,16 & 2,48 & 12,48 & 11,75 \\
\hline 17 & 3,47 & 266,50 & 662,56 & 18,43 & 107,73 & 202,10 & 11,98 & 7,86 & 9,25 & 13,57 \\
\hline 18 & 3,81 & 261,16 & 629,01 & 16,11 & 93,78 & 214,62 & 12,93 & 9,17 & 8,47 & 7,45 \\
\hline 19 & 3,39 & 262,37 & 651,20 & 19,52 & 92,64 & 207,64 & 9,25 & 3,49 & 12,75 & 13,49 \\
\hline 20 & 3,45 & 287,32 & 606,99 & 16,27 & 114,58 & 227,05 & 10,72 & 10,85 & 11,75 & 11,03 \\
\hline $\begin{array}{l}\text { Mean } \\
\text { Total }\end{array}$ & 3,50 & 265,75 & 626,20 & 17 , & 2,06 & 214,65 & 11,04 & 6,49 & 8,42 & 10,35 \\
\hline \multicolumn{11}{|c|}{ Nutrient elements content in sufficient } \\
\hline & $\begin{array}{l}4.00- \\
6.00\end{array}$ & $\begin{array}{l}250.00- \\
660.00\end{array}$ & $\begin{array}{l}680.00- \\
890.00\end{array}$ & $\begin{array}{l}20.00- \\
80.00\end{array}$ & $\begin{array}{l}90.00- \\
340.00\end{array}$ & $\begin{array}{l}190.00- \\
240.00\end{array}$ & $\begin{array}{l}1.70- \\
80.00\end{array}$ & $\begin{array}{l}1.80- \\
100.00\end{array}$ & $\begin{array}{l}0.70- \\
30.0\end{array}$ & $\begin{array}{l}0,80- \\
50.00\end{array}$ \\
\hline
\end{tabular}


Table 3. Aflatoxins content of peanut in the survey areas from harvest and storage

\begin{tabular}{|c|c|c|c|c|c|}
\hline \multirow{2}{*}{ No of samples } & \multicolumn{5}{|c|}{ HPLC (ppb) } \\
\hline & $\mathbf{B}_{1}$ & $\mathbf{B}_{2}$ & $\mathbf{G}_{1}$ & $\mathbf{G}_{2}$ & Total \\
\hline 1 & 0,82 & 0,13 & - & - & 0,95 \\
\hline 2 & 0,45 & 0,27 & - & - & 0,72 \\
\hline 3 & - & - & - & - & 0,00 \\
\hline 4 & 0,74 & 0,56 & - & - & 1,30 \\
\hline 5 & 0,15 & 0,08 & - & - & 0,23 \\
\hline 6 & 0,95 & 0,43 & - & - & 1,38 \\
\hline 7 & 0,47 & 0,11 & - & - & 0,58 \\
\hline 8 & - & - & - & - & 0,00 \\
\hline 9 & - & - & - & - & 0,00 \\
\hline 10 & 0,74 & - & - & - & 0,74 \\
\hline 11 & 0,69 & 0,43 & - & - & 1,12 \\
\hline 12 & 0,83 & - & - & - & 0,83 \\
\hline 13 & 0,37 & 0,15 & - & - & 0,52 \\
\hline 14 & 0,96 & 0,41 & - & - & 1,37 \\
\hline 15 & 0,77 & 0,13 & - & - & 0,90 \\
\hline 16 & 1,05 & - & - & - & 1,05 \\
\hline 17 & 0,21 & - & - & - & 0,21 \\
\hline 18 & 0,97 & 0,22 & - & - & 1,19 \\
\hline 19 & 1,54 & 0,95 & - & - & 2,49 \\
\hline 20 & 1,21 & 0,68 & - & - & 1,89 \\
\hline \multirow{2}{*}{ No of samples } & \multicolumn{5}{|c|}{ HPLC (ppb) } \\
\hline & $\mathbf{B}_{1}$ & $\mathbf{B}_{2}$ & $\mathbf{G}_{1}$ & $\mathbf{G}_{2}$ & Total \\
\hline 1 & 2,15 & 1,81 & - & - & 3,96 \\
\hline 2 & 8,02 & 2,23 & 9,10 & 2,82 & 22,17 \\
\hline 3 & 3,04 & 1,20 & - & - & 4,24 \\
\hline 4 & 7,59 & 1,46 & 7,32 & 1,41 & 17,78 \\
\hline 5 & 7,84 & 2,36 & - & - & 10,2 \\
\hline 6 & 7,52 & 1,91 & - & - & 9,43 \\
\hline 7 & 8,36 & 2,51 & - & - & 10,87 \\
\hline 8 & 6,32 & 2,47 & - & - & 8,79 \\
\hline 9 & 3,09 & 1,41 & - & - & 4,50 \\
\hline 10 & 7,93 & 1,56 & - & - & 7,93 \\
\hline 11 & 4,65 & - & - & - & 4,65 \\
\hline 12 & 4,80 & & - & - & 4,80 \\
\hline 13 & 6,11 & 0,93 & 5,13 & 1,52 & 13,69 \\
\hline 14 & 2,65 & 1,39 & - & - & 4,04 \\
\hline 15 & 4,06 & 2,85 & - & - & 6,91 \\
\hline 16 & 8,27 & - & - & - & 8,27 \\
\hline 17 & 3,41 & 1,42 & - & - & 4,83 \\
\hline 18 & 6,24 & 2,36 & - & - & 8,60 \\
\hline 19 & 4,11 & 1,18 & 2,53 & 0,64 & 8,46 \\
\hline 20 & 6,31 & 1,52 & - & - & 7,83 \\
\hline
\end{tabular}




\section{Discussion}

Althouhg all the seed samples were extensively found to be contaminated by A. niger and A. flavus was very less. Apart from that $A$. parasiticus was less found in due to the development of the peanut seed under the ground, soil-borne pathogens are more affected such as Aspergillus (Hocking, 2003; Kaaya and Warren, 2005). A. niger is seed, soil and air-borne pathogen and contamination of seed batches often exceeds $90 \%$ (Bicici, 2008).

Among the species of $F$. solani and $F$. oxysporum were dominant fungi of peanut seeds. Species of Fusarium cause damping off peanut seedling in cultivation period (Bicici, 1980). Common form-genera isolated were Rhizoctonia, Alternaria, Curvularia, Lasiodiplodia, Nigrospora and Rhizopus. F. solani, F. oxysporum and $F$. equeseti were isolated from all harvest peanut samples in USA (Baird et al., 1993). According to Rasheed et al. (2004), M. phaseolina, R. solani, F. solani, F. oxysporum, A. flavus and A. niger were predominant of 12 groundnut seed samples in Pakistan. The following mycobiota was isolated on the seed samples: nonsporulated fungi (36\%), Penicillium spp. (15\%), Rhizopus spp. (11\%), Fusarium spp. (8\%), Phoma spp. (7\%), Trichoderma spp. (7\%) Cladosporium spp. (4\%), A. flavus (3\%), A. niger (3\%), A. terreus $(2 \%)$ and $F$. verticillioides $(1 \%)$ were isoleted as a common at harvest of the peanut samples in Brazil (Goncalez et al., 2008).

Fungi perform important role of contamination, altering quality and longevity of seeds during the storage (Kakde et al., 2012). A. niger, A. flavus, F. oxysporum, M. phaseolina Penicillium sp. were found predominant at the storage fungi (Jogdand and Talekar, 2010). According to Youssef et al. (2008), A. niger, A. flavus, A. fumigatus, $F$. oxysporum, $P$. citrinum were common fungi and their numbers gained of extension of storage period. About 11 to $87 \%$ of collected peanut samples of storage in Etophia were infected with various moulds including Rhizopus sp., Fusarium sp., Aspergilus flavus, A.niger, other Aspergillus sp., Penicillium sp., and other undefined sp. (Aschalew, 2010). Fungal isolation of peanut seeds in the survey areas from harvest and storage have been similar to these reports.

These fungi could contaminate at prior to harvest or unsuitable harvesting and storage conditions. The results showed that deficiency or excess of nutrients in plants can lead to disease (Elibuyuk et al., 2004). Positive correlation could be between disease occurrence and deficiency of nutrients. Although nutrient element contents are sufficiently, peanut seeds can be contaminated by Aspergillus, Penicillium, Fusarium and Rhizoctonia. As it can be seen in Table 2, deficiency in nutrient element analyses was observed in peanut. Zinc has direct effects on fungal growth. According to Brown et al. (1993), role of Zn deficiency was not effected infection of A. niger. Duffy (2007) also reported that switching from high levels to depletion levels causes a transition from biomass building to citric acid accumulation in Aspergillus niger Tiegh, a fact that is exploited in the food and industrial sectors.

As it can be seen in Table 4, content of nitrogen was also decreased by a range of 3,35 to 3,93\% in harvest and storage. Also, among the mineral content $\mathrm{K}$ showed \% decrease while $\mathrm{P}, \mathrm{S}, \mathrm{Zn}, \mathrm{Fe}, \mathrm{Cu}$ and Mn levels were within the accepted ranges, as well as in storage, generally $\mathrm{Ca}$ levels were under the critical level. When the fungi utilize nutrient minerals for their growth, infected peanut can reduce mineral contents of seed

Nutrients deficiency has diverse effects on the growth and metabolic activities of human body. Diribe and Elom (2002) reported that deficiency of calcium was caused rickets in children and osteomalacia in adults, while low was intake of sodium results in metabolic acidosis. Also, prolonged potassium deficiency was produced serious damage to the kidney.

A lot of isolated fungi have been reported to cause physical and biochemical alters in peanut during storage besides that releasing mycotoxins which tend to limit their use and admissibility (Lima et al., 2000; Amusa et al., 2002; Aliyu and Kutama, 2007). Diener and Davis (1969) also reported that peanuts mycotoxins contamination to be extremely toxic to all animals. Aflatoxin levels during storage were significantly higher than harvest. The present data agreed with Hell et al., 2000; Scheidegger and Payne, 2003; Shapira and Paster, 2004; Kaaya and Warren, 2005; Okello et al., 2010; Lavkor and Bicici, 2015, Lavkor et al., 2017.

The result of our study showed that $\mathrm{N}$ levels were near the minimum critical level or under the level, and other stresses could cause eligibility for infection by Aspergillus species and aflatoxin concentration in peanuts (Table 1, Table 2 and Table 3). Similar reports have been made by Huber and Thompson (2007), nitrogen deficiency and other stressed predispose corn to infection by Aspergillus spp., and aflatoxin concentration in grain was $28 \%$ higher than in $\mathrm{N}$-sufficient plants.

Zinc is especially took for production of aflatoxins by A. flavus. Lee at al. (1966) also reported that about in mat weight was acquired with $0.4 \mu \mathrm{g}$ of zinc per $\mathrm{ml}$, but aflatoxin increased from a low level concentration to approximate $2.0 \mu \mathrm{l}$ of zinc per ml. Zinc deficiency limits aflatoxin production as a result of growth retardation, but zinc absence of any growth effects, demonstrating the regulatory role of zinc, 
and also positive relation have been between the level of zinc and Aspergillus of the plants grown in the soil. Zinc content is correlated with growth and aflatoxin production by A. flavus Link: Fr. and A. parasiticus speare in maize grain, soybeans, sunflower seed and chicken feed. There is a positive relationship between the level of zinc in the soil and saprophytic growth of Aspergillus in the plants grown in that soil (Duffy, 2007). These statements is supporting a positive relationship with adequate zinc levels and the growth of $A$. flavus on peaut seeds (Table 2). Such a similar result was observed by Huber and Thomson (2007), the sufficient amount of zinc, $R$. solani was described as pathogenic and saprophytic infections caused an increase.

As can be seen at Table 2, K levels were generally insufficient. Potassium cause by airborne pathogens diseases also it may be a significant effect on diseases caused by soil-borne pathogens. In addition, $\mathrm{K}$ has effect of reducing the severity of many diseases. In the event of disease, plants of potassium-deficient are more sensitive than potassium-sufficient plants (Prabhu et al., 2007). Reddy and Rao (1980) reported that $F$. solani and F. oxysporum cause damping off groundnut. Bell (1989) also suggested that Fusarium pathogen requires $\mathrm{N}, \mathrm{P}, \mathrm{S}, \mathrm{Mg}$ and $\mathrm{K}$ as macroelements and $\mathrm{Zn}, \mathrm{Mn}$ and $\mathrm{Mo}$ as microelements for optimum growth and sporulation in pure culture. Koseoglu (1995) reported that Fusarium population was effected antagonistic over the potassium; when the K concentration was low, Fusarium was increased; when the K concentration was high, Fusarium increase was inhibited. Fusaric acid and pectin methyl esterase enzyme were produced having a toxic effect by Fusarium pathogens. In addition, zinc played a role both fusaric acid and pectin methyl in producing (Koseoglu, 1995).

The calcium concentration were determined reducing during storage period (Table 2). Similar finding were reported by Wilson et al (1989) that calcium availability in peanuts can affect both Aspergillus group interaction and fungi contamination of peanut kernels. Also, the calcium concentration is negatively correlated with decay caused by fungal pathogens. In this view, application of $\mathrm{Ca}$ was reduced $37 \%$ on apple fruit by $P$. expansum and 43-52\% grapefruit by $P$. digitatum (Rahman and Punja, 2007).

Thus, these fungal infection and contamination from harvest and storage of peanut would be reason it's inedibility, market value decrease and nutrient deficiencies. Furthermore, this situation could related to moisture content and several environmental parameters such as temperature and relative humidity of the harvested peanut previous to storage (Fagbohun and Faleye, 2012).

\section{Conclusion}

A. flavus, A. parasiticus, A. niger, F. solani, F.oxysporum, F sambicinum, F. semitectum $R$. solani, M. phaseolina, R. stolonifer, Penicillium spp. were isolated in both at harvest and from stored peanuts in this study. These fungal colonization and contamination at harvest and stored of peanuts could reduce depletion of its nutrients and store value. Nutrient deficiency or excess could be an important role for the fungal contamination and aflatoxin. Contamination of pathogens apart from the nutrients in the seed; contamination of pathogens in the soil, also climatic differences, not doing crop rotation and may be due to differences in cultural process.

\section{Acknowledgements}

The author is thanks Prof. Dr. Sevcan Oztemiz for providing this research.

\section{References}

Abou-Talip, E. M. E. (1970). Studies on groundnut diseases in U.A.R. Msc thesis, Faculuty. of Agricultural, Alexandria University.

Agrois, G. N. (1997). Plant Pathology, (4th ed.) New York: Academic Press, pp.635.

Arioglu, H. H. (2007). Cultivation and Breeding of Oil Crops. Adana: Cukurova University Publication, pp.204.

Aliy, D, \& Kutama A. (2007). Isolation and Identification of fungal flora associated with groundnut in different storage facilities. Science World Journal, 2(2), 34-36.

Amusa, N. A., Kehinde, I. A., \& Ashaye O. A. 2002. Bio-deterioration of breadfruit (Artocarpus communis) in storage and its effects on the nutrient composition. Afri. J. Biotech. 1(2), 57-60. 
Aschalew, E. L., 2010. Aflatoxin content of peanut (Arachis hypogaea L.) in relation to shelling and storage practice of Ethiopian farmers. MSc thesis, Addis Ababa University School of Graduate Studies Food Science And Nutrition Programme.

Asibuo, J. Y., Arkromah, R., Safo-Kantanka, O., \& Adu-Dapaah, H. K. (2008). Evaluation of nutritional quality of groundnut (Arachis hypogaea L.) from Ghana. African Journal of Food Agricalture Nutrition and Development, 8, 134-141.

AOAC, 1984. Official Method of Analysis. Association of Officail Analytical Chemists, Washington, DC, USA, 14th edition.

AOAC, Official Method (2005): Aflatoxins in corn, raw peanuts and peanut butter. Natural toxins, chapter 49, p. 21.

Baird, R. E., Brenneman, T. B, Mullinix, B. G., Bell, D. K., Culbreath, A. K., \& Moore, J. D. (1993). The effects of chemical treatment, harvest date, and specific isolation media on the peanut shell mycobiota of two peanut cultivars. Plant Disease, 7, 736-741.

Barnett, H. L., \& Hunter, B. B. (1972). Illustrated genera of 1mperfect fungi. Burgess Publishing Company, $3^{\text {rd }}$ edition, p. 241.

Bell, A. (1989). Role of nutrition in diseasse of cotton. In: Engelhard A W, ed., Soilborne Plant Pathogens: Management of Diseases with Macro and Microelements. APS Press, St. Paul, Minnesota, USA, pp. 167-204.

Bicici, M. (1980). Investigations on diseases and aflatoxin caused by Aspergillus flavus Link and Aspergillus niger Van Tieghem in the field harvesting and drying periods of groundnuts Arachis hypoganea L. Ph D thesis, Cukurova University.

Bicici, M., (2008). Disease and Aflatoxin Problem of Peanuts. Farmers [Online] Available: http://www.cu.edu.tr/merkezler/tyhm/2008-04.html. (November 15, 2018)

Brown, P. H., Cakmak, I., \& Zhang, Q. (1993). Form and function of zinc in plants. In: Robson A D, ed., Zinc in Soils and Plants. Kluwer Academic Publishers, Dordrecht, The Netherlands, pp. $93-$ 106.

Booth ,C. (1971). The genus Fusarium. Commonwealth Mycological Institute, Key, Surrey, England. pp. 237.

Diener, U. L., \& Davis, N. D. (1969). Aflatoxin formation by A. flavus. In Aflatoxin: Scientific background control and implications, ed. L. A. Gold blatt, Academic Press, 13-54.

Diribe, C. O., \& Elom, S. O. (2002). Biochemistry in Medicine Vol 11. Immaculate Publishers Ltd. $256 \mathrm{pp}$.

Drahmaputra, O. S., \& Retnowati, I. (1996). Fungi 1solated from groundnuts in some locations of West Java. Biotropia, 9, $15-25$.

Domsch, K. H., Gams, W., \& Anderson, T. H. (1980). Compendium of Soil Fungi. London Academic Press, London.

Duffy, B. (2007). Zinc and plant disease. In: Datnoff L E, Elmer W H, Huber D M, eds., Mineral Nutrition and Plant Disease. The American Phytopathological Society, St. Paul Minnesota, USA, pp. $155-176$. 
Elibuyuk, E. A., Karman, M. R., Inal, A., \& Ozer, Z. (2004). The interactions of plant diseases and pests with nutrition of plants. In: 3rd National Congress of fertilizers in Turkey, Agriculture Industry Environment Proceedings Book. Tokat, Turkey.

Ellis, M. B. (1971). Dematiaceous Hyphomycetes. Commonwealth Mycological Institute, Kew, Surrey, England, pp.608.

El-Akkad, S. A. F. (1982). Pathological studies on pod rot diseases of peanut. M.Sc. thesis, Faculty of Agriculture, Cairo University, Egypt.

El-Khadem, M., Naguib, M. M., \& Abdel-Ghani, A. K. (1975). Aflatoxin in food stuff in Egypt peanut mycoflora and toxicity. Microbiologia, 12, 29-36.

Fagbohun, E., \& Faleye, O. S. 2012. The Nutritional and mycoflora changes during storage of groundnut (Arachis hypogea L.). International Journal of Agronomy and Agricultural Research, $2,15-22$.

Freeman, A. F., Morris, N. J., \& Willich, R. K.. (1954). Peanut Butter. U.S. Dept. Agr. AIC-370.

Failla, L. J., Lynn D., \& Niehaus W. G., (1986). Correlation of $\mathrm{Zn}^{2+}$ Content with Aflatoxin Content of Corn. Applied and Environmental Microbiology, 52(1): 73-74.

Goldblatt, L. A. (1969). Aflatoxin. Scientific background, control and implications. Academic Press, New York. 472 pp.

Goncalez, E., Nogueira, J. H. C., Fonseca, H., Felicio, J. D., Pino, F. A., \& Corrêa, B. (2008). Mycobiota and mycotoxins in Brazilian peanut kernels from sowing to harvest. Int. J. Fd. Microbiol, 123, 184-190.

Hell, K., Cardwell, K. F., Setamou, M., \& Poehling, H. M. (2000). The influence of storage practices on aflatoxin contamination in maize in four agroecological zones of Benin, West Africa. Journal of Stored ProductsResearch, 36(4): 365-382

Hocking, A. D. (2003). Microbiological facts and fictions in grain storage. In: Proceedings of the Australian Postharvest Technical Conference, Canberra, Australia.

Huber, D. M. (1980). The role of mineral nutrition in defense. In: Horsfall J G, Cowling E B, eds., Plant disease an advanced treatise, Academic Press, New York, NY. pp. 381-406.

Huber, D. M., \& Thompson, I. A. (2007). Nitrogen and plant disease. In: Datnoff L E, Elmer W H, Huber D M, eds., Mineral Nutrition and Plant Disease. The American Phytopathological Society St. Paul, Minnesota, USA. pp. 31-44

Ingale, S., \& Shrivastava, S. K.. (2011). Nutritional study of new variety of groundnut (Arachis hypogaea L.) JL-24 seed. African Journal of Food Science, 5, 490-498.

Jogdand, S. K., \& Talekar, S. M. (2010). Fungal population on seeds of Arachis Hypogea L. Journal of Ecobiotechnology, 2, 11-13.

Payne, G. A., Kamptarth, E. J., \& Adkins, C. R. (1989). Increased aflatoxin contamination in nitrogenstressed corn. Plant Disease, 73, 556-559.

Pitt, J. I. (2000). A Laboratory Guide to Common Penicillium Species. Food Science, Australia, pp. 197.

Porter, D. M., Smith, D. H., Rodriguez-Kabana, R. (1990). Compendium of Peanut Diseases. American Phytopathological Society Press, St. Paul. Minenesota, USA. 
Prabhu, A. S., Fageria, N. K,. \& Huber, D. M. (2007). Potassium and plant disease. In: Datnoff L E, Elmer W H, Huber D M, eds., Mineral Nutrition and Plant Disease. The American Phytopathological Society, St. Paul, Minnesota, USA. pp. 57-78

Pursglove, J. W. (1984). Tropical Crops Dicotyledons. John Wiley New York. pp. 2791.

Rahman, M., \& Punja, Z. K. (2007). Calsium and plant disease. In: Datnoff L E, Emler W H, Huber D M, eds., Mineral Nutrition and Plant Disease. The American Phytopathological Society St. Paul, Minnesota, USA. pp.79-94.

Raper, B. K., \& Fennel, D. I. (1977). The Genus Aspergillus. Robert Ekriege Publishing Company, New York. pp. 686.

Reddy, M. N., \& Rao, A. S. (1980). Damping off of groundnut caused by 2 Fusarium spp., F. solani and F. oxysporum. Indian Journal of Mycology and Plant Pathology, 10, 65-66.

Richardson, M. J. (1990). An Annotated List of Seed Borne Diseases. International Seed Association, Zurich, Switzerland. pp. 320.

Kaaya, N. A, \& Warren, H. L. (2005). A review of past and present research on aflatoxin in Uganda. African Journal of Food Agriculture and Nutritional Development, 5, 1- 2005.

Kadiroglu, A. (2008). Cultivation of Peanut. West Mediterranean Agricultural Research Institute, Antalya. pp. 54.

Kakde, R. B., Badar, K. V., Pawar, S. M., \& Chavan, A. M. (2012). Storage mycoflora of oilseeds: a review. International Multidisciplinary Research Journal, 2, 39-42.

Klich, M. A. (2002). Identification of Common Aspergillus Species. CBS, Utrecht, The Netherland. pp. 163.

Koseoglu, T. (1995). The Relationship of Plants Nutrition and Health. Mediterranean University, Faculty of Agriculture, Issue No: 5 Antalya, pp. 70.

Lavkor, I. (2013). Control of diseases and aflatoxin occurrences with proper cultural and disease management practices in peanut growing. Ph.D thesis, Cukurova Unversity.

Lavkor, I. (2015). Lavkor I, Bicici M. Aflatoxin occurrence in peanuts grown in osmaniye at harvest, post-harvest, drying and pre-storage periods. Journal of Agricultural Sciences. 21, 394-405.

Lavkor, I., Var, I., Oztemiz, S., \& Almatar, M. (2017). First report of mycotoxins in second peanuts crop in Adana and Osmaniye at harvest, drying, pre-storage and storage periods. Aflatoxin-Control, Analysis, Detection and Health Risks. Ed: Abdulra'uf L. B. Croatia: InTech Open Science. pp. 193-208

Lee, E. G. H., Townsley, P. M., \& Walden, C. C. (1966). Effect of bivalent metals on the production of aflatoxins in submerged cultures. Journal of Food Sci., 31, 432-436.

Lima, C. A. P., R. B. Orsi, P. Dilkin, \& Correa, B. (2000). Mycoflora and Aflatoxigenic species in derivatives of milled rice. Science Tech. 2, 1-7.

Nelson, E. P., Toussoun, T. A., \& Marasas, W. F. O. (1983). Fusarium Species: an Illustrated Manual for Idetification. The Pennsylvania State University Press, University Park and London. pp.193.

Nielsen, K. .F., Mogensen, J. M., Johansen, M., Larsen, T. O., \& Frisvad, J. C. (2009). Review of Secondary Metabolites and Mycotoxins from Aspergillus niger group Anal. Bioanal. Chem. 95: 1225-1242. 
Okello, D. K., Biruma, M. \& Deom, C. M. (2010). Overview of groundnuts research in Uganda: past, present and future. African Journal of Biotechnology, 9(39): 6448-6459

Rasheed, S., Dawar, S., Ghaffar, A., \& Shaukat, S. S. (2004). Seed-borne mycoflora of groundnut. Pak. J. Bot. 36, 199-202.

Savage, G. P., \& Keenan, J. I. (1994). The composition and nutritive value of groundnut kernels. In: Smart J, ed., The Groundnut Crop: Scientific Basis for Improvemen. Chapman and Hall, London. pp. 173-213.

Scheidegger, K. A., \& Payne, G. A. (2003). Unlocking the secrets of Aspergillus flavus from pathogenicity to functional genomics, Journal of Toxicology-Toxin Review, 22(2-3): 423-459

Shapira, R., \& Paster, N. (2004). Control of mycotoxins. In: N Magan \& M Olsen (Eds) Storage and Techniques for their Decontamination in: Mycotoxins in Food, Woodhead Publishing Limited, Cambridge CB1 6AH, England.

Sullivan, G. A. (1984). Seed and seedling diseases In: Porter D M, Smith D H, Rodriguez K, eds., Compendium of Peanut Diseases. St. Paul, Minnesota, USA, American Phytopathological Society. pp.37-38.

Summerell, B. A., Salleh, B., \& Leslie, J. F. (2003). A utilitarian approach to Fusarium identification. Plant Disease, 87, 117-128.

Varga, J., Frisvad, J. C, \& Samson, R. A. (2009). A Reappraisal of Fungi producing aflatoxins. World Mycotoxin Journal 2(3): 263-277.

Wilson, D. M., Walker, M. E., \& Gascho, G. J. (1989). Some effects of mineral nutrition on aflatoxin contamination of corn and peanuts. In: Engelhard A W, ed., Soilborne Plant Pathogens: Management of Diseases with Macro and Microelements. APS Press, St. Paul, Minnesota, USA. pp. 137-151.

Youssef, M. S., El-Maghraby, O. M. O., \& Ibrahim, Y. M. (2008). Mycobiota and mycotoxins of egyptian peanut (Arachis hypogeae L.) seeds. International Journal of Botany, 4, 349-360, 2008. 